\title{
Effects of Different Irrigation Management Practices on Potato (Solanum tuberosum L.)
}

\author{
Trevor W. Crosby and Yi Wang *(i)
}

\footnotetext{
check for updates

Citation: Crosby, T.W.; Wang, Y. Effects of Different Irrigation Management Practices on Potato (Solanum tuberosum L.). Sustainability 2021, 13, 10187. https://doi.org/ $10.3390 /$ su131810187
}

Academic Editor: Gonçalo C. Rodrigues

Received: 2 July 2021

Accepted: 9 September 2021

Published: 12 September 2021

Publisher's Note: MDPI stays neutral with regard to jurisdictional claims in published maps and institutional affiliations.

Copyright: (C) 2021 by the authors Licensee MDPI, Basel, Switzerland. This article is an open access article distributed under the terms and conditions of the Creative Commons Attribution (CC BY) license (https:/ / creativecommons.org/licenses/by/ $4.0 /)$.
Department of Horticulture, University of Wisconsin-Madison, Madison, WI 53706, USA; twcrosby@wisc.edu

* Correspondence: wang52@wisc.edu

\begin{abstract}
Decisions in irrigation management can greatly impact the overall sustainability of potato production. A field study was conducted in 2018 and 2019 to evaluate the impacts of different irrigation regimes on yield and quality of three russet potato varieties. For Russet Burbank, fry quality at harvest and at 4 and 8 months after harvest was assessed. During early growth stages, the standard practice of irrigating to maintain $60-80 \%$ soil moisture was employed. The irrigation treatments were applied during the late tuber bulking and maturation growth stages, and consisted of irrigation at $125 \%, 100 \%, 75 \%$, and $50 \%$ of daily evapotranspiration (ET). We found that $125 \% \mathrm{ET}$ provided no increase in total yield and marketable yield compared to other treatments in 2018, and it produced similar marketable yield to $100 \%$ ET in 2019. Total yield, but not marketable yield, of $125 \%$ ET and $100 \%$ ET was significantly higher than the number under 50\%ET in 2019. In both years, increasing irrigation rate led to a decrease in irrigation efficiency and water-use efficiency. Irrigation rate had no significant effects on tuber quality at harvest and during storage. This study indicated that over-irrigation at $125 \%$ ET was not beneficial to profitable potato production in the Upper Midwest of the US, and deficit irrigation at $75 \%$ ET during late tuber bulking and tuber maturation could potentially result in more sustainable water use while not jeopardizing tuber growth. The results support the possibility of adopting late-season deficit irrigation for growing potatoes in the region, though more years of research would allow for a better understanding of the impacts of this practice.
\end{abstract}

Keywords: Solanum tuberosum L.; irrigation efficiency; water use; yield; crop quality

\section{Introduction}

Potato (Solanum tuberosum L.) is an important food crop with a wide range of growing locations around the world [1]. Globally, over 375 million tons of potatoes were produced in 2016 [1]. Potatoes in the United States produce a raw product value of about USD 4 billion per year and are planted on around 400,000 hectares of land [2]. In Wisconsin, which ranks as number three in the United States for potato production, potatoes are planted on 27,000 hectares of land, and potato production creates about USD 350 million in annual economic activity and over 2750 jobs statewide [2,3]. Approximately 50\% of Wisconsin's potatoes are sold for fresh market consumption and the other half are used for French fry or chip processing [2] (Keene and Mitchell, 2010).

Compared to other crops, potatoes have a shallow rooting zone, high susceptibility to water stress, and a low water stress threshold required to close their stomata [4,5]. In addition, they are generally grown on soils that have low water-holding capacity, such as the sandy soils of the Central Sands in Wisconsin [5,6]. The Central Sands region is a sandy outwash plain marked by extremely coarse texture (90\% sand) with a low soil organic matter content $\left(<10 \mathrm{~g} \mathrm{~kg}^{-1}\right)$ and a relatively shallow groundwater table $(0.9-$ $11 \mathrm{~m}$ ) [7]. In this region, irrigated agriculture has increased from 15,000 hectares in the 1960 s to 74,000 hectares in 2000 , while domestic water withdrawals have not significantly increased [8]. The presence of irrigation in the Central Sands reduces the availability of groundwater as well as the volume of surface water bodies [7]. Kraft et al. [8] found 
that agricultural irrigation in the Central Sands has significant impact on the base flow of streams and water level in aquifers, lakes, and wetlands. In addition, heavily farmed areas with large amounts of irrigation in this region have been shown to strongly correlate with excessive amounts of nitrate contamination (greater than $10 \mathrm{mg} / \mathrm{L}$ of $\mathrm{NO}_{3}-\mathrm{N}$ ) in the groundwater [9], which has been a pressing challenge in recent years. Phosphorous leaching can also occur in some irrigated cropping systems, although this is not a significant issue in the Central Sands region.

Regulated deficit irrigation is a strategy that reduces or removes irrigation during crop growth stages that are drought-tolerant in order to maximize water-use efficiency [10] (Geerts and Raes, 2009). The overarching goal of regulated deficit irrigation is reducing evaporative water loss and avoiding excessive water use, while optimizing crop yield and quality and eliminating pests and diseases that would thrive in wet or humid environments [10-12]. Through deficit irrigation, yield and plant health can remain stable while the water needed to maintain the crop is minimized. Regulated deficit irrigation may also reduce the possibilities of nitrogen leaching, leading to better nutrient uptake in crops as well as reduced water quality degradation [13].

Potato crops can undergo yield reductions when soil moisture deviates by only $10 \%$ [14]. Water stress can reduce leaf area through wilting and leaf elongation as well as reduce the amount of photosynthesis that takes place in a given leaf area through stomatal closure [15]. However, the optimal amount of water needed can vary, depending on the characteristics of the plant, soil, and climate [15]. Additionally, tuber production can suffer in terms of yield, size, and disease incidence from both under- and over-irrigation due to increased disease pressure, decreased soil aeration, and nutrient leaching $[11,12,16]$.

The tuber bulking stage is the growth period that determines a large part of tuber yield and quality [15]. During this phase, tuber growth rates are relatively linear as sucrose moves from the leaves to the tubers and is converted to starch, and the tubers accumulate water, nutrients, and carbohydrates [5]. Tubers can be remarkably susceptible to water stress that is related to misshaping or poor quality during the tuber bulking stage [17]. Many studies have indicated that water stress during tuber initiation and early tuber bulking can decrease tuber yield and quality [18-21]. The study of Stark et al. [22] conducted in Idaho concluded that providing full irrigation through mid-bulking followed by a slow reduction in irrigation amounts was the best scenario for reducing yield losses when water supplies were deficient. Aside from this yield analysis, little recent data are available about the impact of irrigation on the latter part of tuber bulking stage and the tuber maturation stage.

The objective of this study was to evaluate the yield, quality, irrigation efficiency, water-use efficiency, and post-harvest storability of common Wisconsin russet potato varieties that were subjected to different irrigation rates during the late tuber bulking and tuber maturation growth stages. The ultimate goal is to provide useful information that growers can use to make management decisions to achieve more sustainable irrigation management, to save operation costs associated with unneeded irrigation events, and to improve stewardship of the invaluable water resource for potato production.

\section{Materials and Methods}

\subsection{Experimental Design and Agronomic Practices}

This study took place over the course of the 2018 and 2019 field seasons and the 2018 storage season at the Hancock Agricultural Research Station (HARS) in Hancock, WI (latitude: $44^{\circ} 12.1413 \mathrm{~N}$; longitude $89^{\circ} 53.6840$; elevation $328 \mathrm{~m}$ ). The soil type of the field was a loamy fine sand (organic matter $<1 \%$ ) from a depth of 0 to $45 \mathrm{~cm}$ and was a fine sand (organic matter $<0.5 \%$ ) from a depth of 45 to $75 \mathrm{~cm}$ (Supplemental Table S1). Soils in the area have an average permanent wilting point was $0.055 \mathrm{~m}^{3} \mathrm{~m}^{-3}$, an average field capacity of $0.162 \mathrm{~m}^{3} \mathrm{~m}^{-3}$, and an average available water content of $0.107 \mathrm{~m}^{3} \mathrm{~m}^{-3}$ [23]. For the standard irrigation treatment, the maximum allowed soil water deficit was $40 \%$. Irrigation was scheduled according to weather and crop conditions such that this maximum 
allowed deficit was not passed, with the goal of maintaining $60-80 \%$ soil moisture. Other pre-planting soil test results are shown in Supplemental Table S2.

This experiment was a two-factor factorial design with four blocks, with irrigation rate and variety as the two factors. The irrigation rates are listed in Table 1 , and the varieties were Russet Burbank, Russet Norkotah, and Silverton. Each plot contained four $7.6 \mathrm{~m}$ rows of each variety with $0.3 \mathrm{~m}$ seed spacing and $0.9 \mathrm{~m}$ row spacing. For each variety, the outer two rows were guard rows to mitigate any variations resulting from edge effects, and the inner two rows were dug for at-harvest and post-harvest sampling. A weather station (Campbell Scientific, Logan, UT, USA) was located within $500 \mathrm{~m}$ of experimental plots to record precipitation and temperature data. Accumulated growing degree days (GDD) were calculated from 1 May to 1 July in 2011 to 2019 using the formula GDD = [min temperature $+\max$ temperature] $\left./ 2-7^{\circ} \mathrm{C}\right]$.

Table 1. Irrigation treatments that were applied in this study.

\begin{tabular}{ll}
\hline \multicolumn{1}{c}{ Irrigation Rate } & \multicolumn{1}{c}{ Treatments } \\
\hline 1-over irrigation & Irrigation at $125 \% \mathrm{ET}$ \\
\hline 2-standard irrigation & $\begin{array}{l}\text { Irrigation at } 100 \% \mathrm{ET} \text {, which is the standard treatment of } \\
\text { this study }\end{array}$ \\
\hline 3-deficit irrigation 1 & Irrigation at 75\%ET \\
\hline 4-deficit irrigation 2 & Irrigation at 50\%ET \\
\hline t5-deficit irrigation 3 & $\begin{array}{l}\text { Irrigation at 75\%ET starting on 25 July, and then at 50\%ET } \\
\text { starting on 20 August. This treatment was only applied in } \\
\text { 2019. }\end{array}$ \\
\hline
\end{tabular}

thate 5 was only applied in 2019.

Seed potato pieces were planted on 1 and 2 May in 2018, and on 3 and 6 May in 2019. Emergence occurred on around May 20th of each year, and tuber initiation took place in the first week of June in each year. Irrigation management was performed with a linear overhead nozzle-controlled variable rate irrigation (VRI) system (Reinke Irrigation Company, Deshler, NE, USA) paired with a remote precision controller (Reinke Irrigation Company, Deshler, NE, USA) with touch technology and GPS. The system was $392 \mathrm{~m}$ wide and $764 \mathrm{~m}$ long. The sprinkler package was a Nelson Irrigation Model 03030 with nozzles rated at $28 \mathrm{~L}$ per minute. The nozzles are 30 to $35 \mathrm{psi}$ inlet pressure regulated to $10 \mathrm{psi}$ outlet side. The sprinklers had a height of $2.3 \mathrm{~m}$ and a spacing of $2.9 \mathrm{~m}$. The overall system had a flow rate of $1934 \mathrm{~L}$ per minute.

Watering at $100 \%$ evapotranspiration (ET) is a standard practice at HARS as well as in the Wisconsin potato industry. In both years, all plots received irrigation at $100 \% \mathrm{ET}$ before 25 July, which was the beginning of the irrigation treatment period. The date 25 July was chosen as it represented the average date across the three varieties to reach late tuber bulking, and 20 August was chosen as the date to change application rates in treatment 5 (Table 1) because it was during the tuber maturation stage. All irrigation treatments ended at vine kill, which occurred on 10 September in 2018 and 9 September in 2019. The vine kill date was 14 days before harvest. Daily ET was estimated by the Wisconsin Irrigation Scheduling Program using the Priestley-Taylor equation [24]:

$$
\lambda_{\mathrm{v}} \mathrm{ET}_{\mathrm{pm}, \mathrm{o}}=\left[\Delta \cdot\left(\mathrm{R}_{\mathrm{n}}-\mathrm{G}\right)+\varrho_{\mathrm{a}} \cdot \mathrm{c}_{\mathrm{p}} \cdot\left(\left(\mathrm{e}_{\mathrm{s}}-\mathrm{e}_{\mathrm{a}}\right) / \mathrm{r}_{\mathrm{a}}\right)\right] /\left[\Delta+\gamma \cdot\left(1+\mathrm{r}_{\mathrm{s}} / \mathrm{r}_{\mathrm{a}}\right)\right]
$$

where $\mathrm{ET}_{\mathrm{pm}, \mathrm{o}}$ is Penman-Monteith evapotranspiration in $\mathrm{m}^{-1}{ }^{-1} ; \lambda_{\mathrm{v}}$ is volumetric latent heat of vaporization, $2453 \mathrm{MJ} \mathrm{m}^{-3} ; \Delta$ is slope of the saturation vapor pressuretemperature curve $\left(\mathrm{kPa} \mathrm{C}^{-1}\right) ; \mathrm{R}_{\mathrm{n}}$ is net radiation $\left(\mathrm{MJ} \mathrm{m}^{-2}\right.$ day $\left.^{-1}\right) ; \mathrm{G}$ is soil heat flux density $\left(\mathrm{MJ} \mathrm{m}^{-2} \mathrm{day}^{-1}\right) ; \varrho_{\mathrm{a}}$ is air density for a given air pressure $\left(\mathrm{kg} \mathrm{m}^{-3}\right) ; \mathrm{c}_{\mathrm{p}}$ is specific heat of air $\left(\mathrm{MJ} \mathrm{kg}^{-1} \mathrm{C}^{-1}\right)$; $\mathrm{e}_{\mathrm{s}}$ is saturation vapor pressure $(\mathrm{kPa}) ; \mathrm{e}_{\mathrm{a}}$ is actual vapor pressure $(\mathrm{kPa})$; 
$\mathrm{r}_{\mathrm{a}}$ is air resistance $\left(\right.$ day $\left.\mathrm{m}^{-1}\right) ; \gamma$ is the psychrometric constant $\left(\mathrm{kPa} \mathrm{C}^{-1}\right)$; and $\mathrm{r}_{\mathrm{s}}$ is surface resistance $\left(\right.$ day $\mathrm{m}^{-1}$ ).

The irrigation rates used in this study were chosen to cover a wide spectrum of possible irrigation scenarios.

All other cultural practices including fertilization and pest management were based on the University of Wisconsin-Madison Extension's recommendation [25]. Total nitrogen applied was $340 \mathrm{~kg} \mathrm{~N} \mathrm{ha}^{-1}$, and application was split between planting, hilling, tuber initiation, early tuber bulking, and mid tuber bulking. The starter fertilizer was 6-30-22-4S. The hilling application was accomplished using side-dressing, where 21-0-0-24S ammonium sulfate was applied. All other applications were accomplished using an airflow fertilizer applicator, where dry 34-0-0 ammonium nitrate was applied (Supplemental Table S3).

To monitor soil moisture content during the growing season, a water content reflectometer sensor (WCR) (model CS616, Campbell Scientific, Logan, UT, USA) was installed at two depths $(30$ and $60 \mathrm{~cm}$ ) in one replication of each treatment. The sensors were installed in the first row of each subplot containing Russet Burbank. The WCR sensors recorded daily soil volumetric water content at 15 -minute intervals.

\subsection{In-Season Weather}

Precipitation totals for the entire growing season and for the treatment period alone (25 July to vine kill) are shown in Table 2.

Table 2. Precipitation during the entire growing season and during the treatment period, and average daily temperature for the month of May, June, July, and August in 2018 and 2019.

\begin{tabular}{cccccccc}
\hline \multirow{2}{*}{ Weather Data } & \multicolumn{2}{c}{ Precipitation $(\mathbf{c m})$} & \multicolumn{3}{c}{ Average Daily Temperature $\left({ }^{\circ} \mathbf{C}\right)$} \\
\cline { 2 - 8 } & During Growing Season & During Treatment Period & May & June & July & August \\
\hline $\mathbf{2 0 1 8}$ & 49.80 & 27.61 & 18.1 & 20.5 & 22.3 & 21.7 \\
\hline $\mathbf{2 0 1 9}$ & 50.72 & 9.96 & 11.2 & 19.3 & 22.2 & 19.0 \\
\hline
\end{tabular}

Daily irrigation and precipitation data for the 2018 and 2019 growing seasons are shown in Figure 1. In 2018, there were three periods of high rainfall $(>2.5 \mathrm{~cm}$ per rain event) that largely disrupted irrigation treatments. These periods took place from 14 June to 22 June, 19 July to 23 July, and 21 August to 9 September (Figure 1A). The intense rainfall period between 21 August and 9 September caused the second irrigation treatment of rate 5, which was expected to start on 20 August at a rate of 50\%ET, to be disrupted and not to be effectively applied. In 2019, there were erratic rainfall events $(<2.5 \mathrm{~cm})$ throughout the treatment period (Figure 1B). 


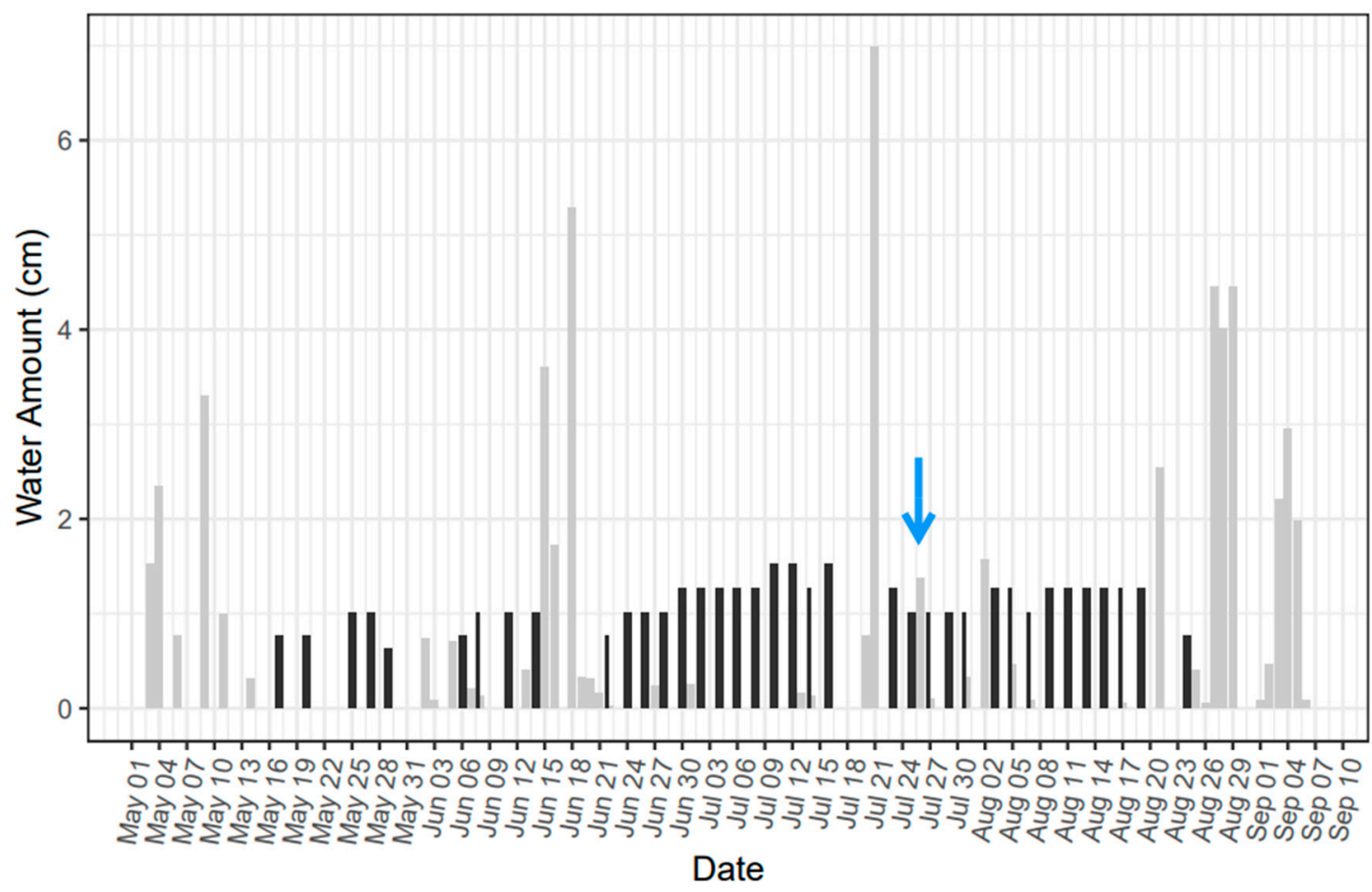

Water Type

$\square$ Irrigation Precipitation

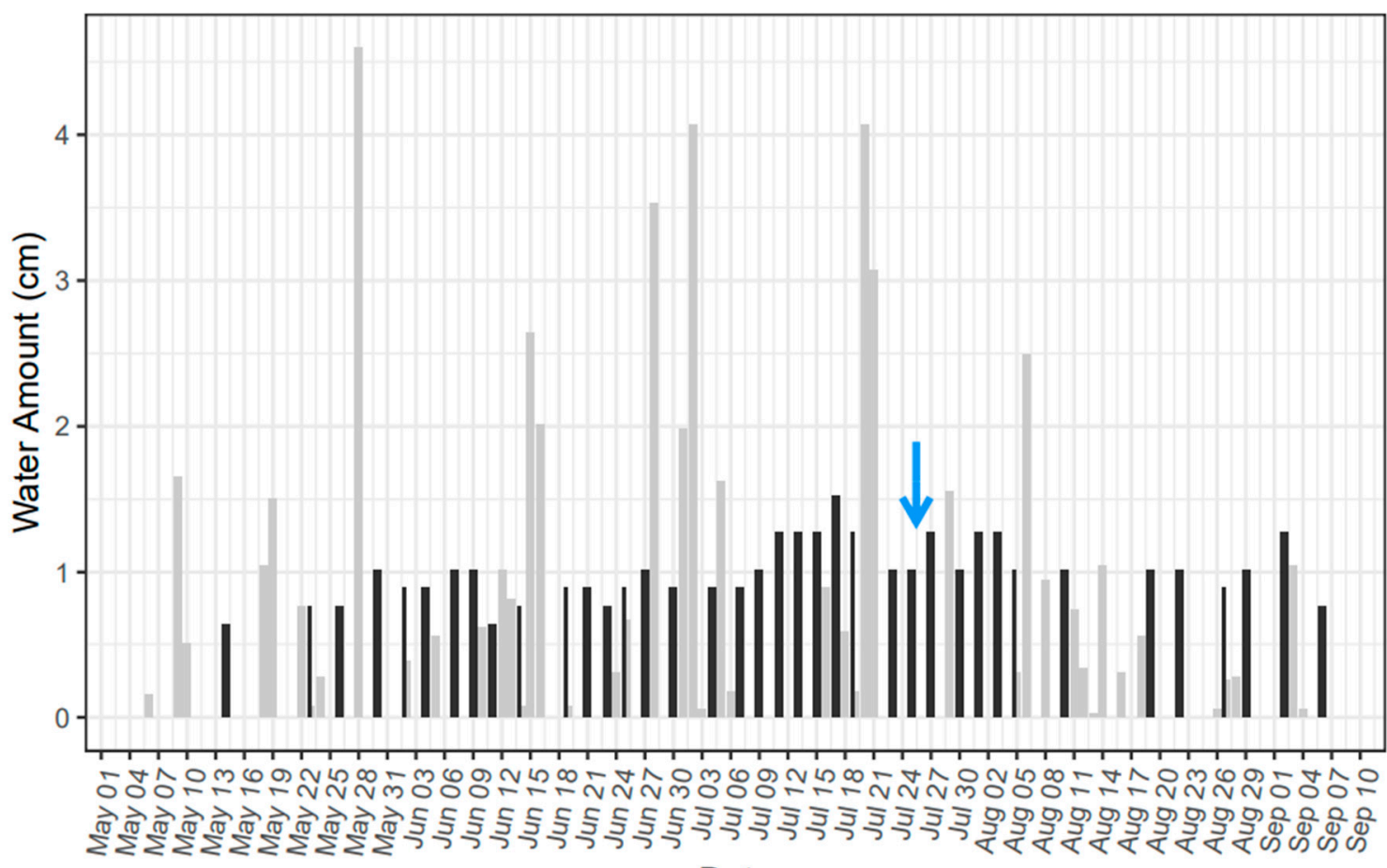

Water Type

Irrigation

Precipitation

Date

Figure 1. Irrigation and precipitation records of UW Hancock Agricultural Research Station in 2018 (A) and 2019 (B). The arrow in each graph indicates date of irrigation treatment initiation (25 July).

\subsection{Harvest Practices}

All plots were harvested on 24 September 2018 and 23 September 2019 using a tworow digger (Gallenberg Technologies, Antigo, WI, USA). Tuber yield and quality were determined by assessing total final plot weight, total final weight of marketable tubers, specific gravity, and internal defects. The tubers were washed and graded for their individ- 
ual weight using an AgRay Vision x-ray grading machine (AgRay Vision, Acampo, CA, USA). Tubers that were misshapen, rotten, or green due to sunlight exposure were culled before being graded. The year 2019 had an unusually high number of green tubers due to late season precipitation washing away topsoil. Cull weights were recorded in their own category and counted towards total yield from each plot.

Grading was categorized according to the following size profile based on individual tuber weight: 0-113 g, 113-170 g, 170-283 g, 283-367 g, and greater than $367 \mathrm{~g}$. Marketable yield was then calculated as the yield of non-culled tubers that were larger than $170 \mathrm{~g}$. In this study, no tubers bigger than $510 \mathrm{~g}$ were observed. These values were chosen to reflect regional industry standards.

Ten tubers from each plot weighing $170 \mathrm{~g}$ to $280 \mathrm{~g}$ each were randomly chosen to determine specific gravity as well as internal defects. Specific gravity was measured using a Weltech PW-2050 Dry Matter Assessment System. After taking the weight of a 2000-3000 g sample of tubers in the air and in water, the system used the following formula to calculate the specific gravity for the sample [26]:

$$
\text { Specific gravity }=(\text { Weight in air }) /(\text { Weight in air }- \text { weight in water })
$$

To assess internal defects, a separate sample of 10 tubers ( $170 \mathrm{~g}$ to $280 \mathrm{~g}$ ) from each plot were cut in half from stem end to bud end to evaluate incidence of hollow heart.

Irrigation efficiency (IE) was defined as the ratio of the yield produced by the crop to amount of water supplied to the crop through irrigation. This efficiency was calculated as yield (in megagrams per hectare) divided by the total amount of irrigated water (measured in centimeters) applied over the course of the entire growing season. Water-use efficiency (WUE) was defined as the ratio of the yield produced by the crop to the amount of all water supplied to the crop and was calculated as yield divided by the total amount of precipitation and irrigation over the entire growing season. Both total yield and marketable yield were considered for these calculations. The major difference between these two efficiencies is that water-use efficiency considers all water that the crop receives, while irrigation efficiency disregards precipitation and only considers the yield achieved in relation to the amount of irrigation water applied.

\subsection{Storage Management}

After harvest, about $20 \mathrm{~kg}$ of healthy potatoes from each plot were placed into the University of Wisconsin Hancock Potato Storage Research Facility, which was maintained at $12.8{ }^{\circ} \mathrm{C}$ for the purpose of wound healing for thirty days. Temperatures were then decreased at a rate of $0.3^{\circ} \mathrm{C}$ per day to a final holding temperature of $8.9^{\circ} \mathrm{C}$. The sprout inhibitor, Isopropyl N-(3-chlorophenyl)carbamate (CIPC, Decco Chemical, at 78.6\% active ingredient), was applied to all tubers as a thermal aerosol at a rate of $22 \mathrm{mg} \mathrm{kg}^{-1}$ right before ramping temperature down to the holding temperature. Relative humidity was maintained at $95 \% \pm 3 \%$ and $\mathrm{CO}_{2}$ level was kept below $3600 \mathrm{mg} \mathrm{m}^{-3}$ throughout the entire duration of storage.

Storage data were collected for the 2018 and 2019 storage seasons. Data were collected at the time of harvest as well as at 16 and 32 weeks after harvest. Only Russet Burbank was evaluated due to its use for fry processing purpose.

\subsection{Fry Color Analysis}

One fried plank $(3.0 \mathrm{~cm} \times 0.8 \mathrm{~cm} \times$ length of tuber) from a 10-tuber sample from each variety/irrigation treatment/block was used for fry color determination within one week of harvest and then at 16 and 32 weeks in storage. This range of dates was recommended by regional industry potato storage experts. Planks were fried in canola oil at $191{ }^{\circ} \mathrm{C}$ for $3.5 \mathrm{~min}$ and blotted dry to remove extra oil. Fry color was determined within the first 3 min after frying using a model 577 Photovolt Reflectometer (model 577, Photovolt Instruments Inc., Minneapolis, MN, USA). As per the manufacturer's recommendation, a green filter was used and calibrated, using a black-cavity standard as $0.0 \%$ reflectance 
and a white plaque as $99.9 \%$ reflectance. Measurements were taken on the bud and stem ends of each plank. A relationship between the USDA standard fry color and the photovolt reflectance was previously established. A USDA fry color rating 1 is equal to a 44.0 or greater reflectance reading, a USDA 2 rating is less than 44.0 to 35.0 reflectance reading, a USDA 3 rating is less than 35.0 to 26.0 reflectance reading, and a USDA 4 rating is less than 26.0 reflectance reading [17]. Therefore, higher photovolt reflectance readings are associated with lighter fry color. In 2019, fry color evaluation at harvest and after 32 weeks of storage were measured based on photovolt readings, whereas fry color assessment at 16 weeks of storage used USDA ratings. Due to the different rating systems, an ANOVA was not run on the fry color data in 2019.

\subsection{Sugar Analysis}

Sucrose and glucose content were determined on the same 10-tuber sample used for the fry color determination by the method of Sowokinos et al. [27] with modifications. Two hundred grams of tuber samples were sliced from both the stem end and bud end of Russet Burbank tubers. Samples were then juiced using an Acme Supreme Juicerator (Acme Equipment, Spring Hill, FL, USA) mixed with a $50 \mathrm{mM}$ phosphate buffer. This phosphate buffer was a sodium phosphate monobasic and dibasic mixture. The samples were placed in a refrigerator for a minimum for $30 \mathrm{~min}$, then a $1 \mathrm{~mL}$ sample from the top of the container was extracted. A YSI 2900 Select Biochemistry Analyzer (Sigma-Aldrich, St. Louis, MO, USA) was used to analyze sucrose and glucose concentration.

\subsection{Data Analysis}

Data analysis was performed following a two-factor factorial design, with irrigation treatment and variety as the two factors, and variability between the four blocks as the error term. Data from 2018 and 2019 seasons were analyzed separately due to variable weather conditions in those two years. Analysis of variance (ANOVA) was conducted in $\mathrm{R}$ [28]. Means were separated using Tukey's test at the $\alpha=0.05$ level.

\section{Results}

\subsection{Soil Moisture, Growing Degree Days, and Water Balance}

Volumetric water content (VWC) at two soil depths are shown in Figures 2 and 3 for the 2018 and 2019 growing seasons, respectively. In both years, the soil water content of the topsoil $(0-30 \mathrm{~cm})$ and subsoil $(30-60 \mathrm{~cm})$ had similar values among treatments before the start of the treatment period on 25 July. After that date, rate 1 (the over-irrigation treatment) had higher VWC values than rate 2 (the standard irrigation), particularly at the subsoil depth. Rate 3 and rate 4 (the two deficit irrigation levels) had lower VWC values at the top soil depth compared to rate 2 (the standard irrigation), and the difference was more obvious in 2018. In 2019, rate 5 had similar soil VWC changes as rate 4, although the topsoil values were slightly higher under rate 5 during most of the treatment period (Figure 3 ). Throughout the growing season, the topsoil had more changes in VWC values within each day, which was indicated by the daily spike approximately at midnight, than the subsoil. The different irrigation treatment effects were more closely reflected by the VWC data in 2018 than in 2019, possibly due to precipitation in 2019 throughout the treatment period that can disrupt the irrigation treatments (Figure 1B). 


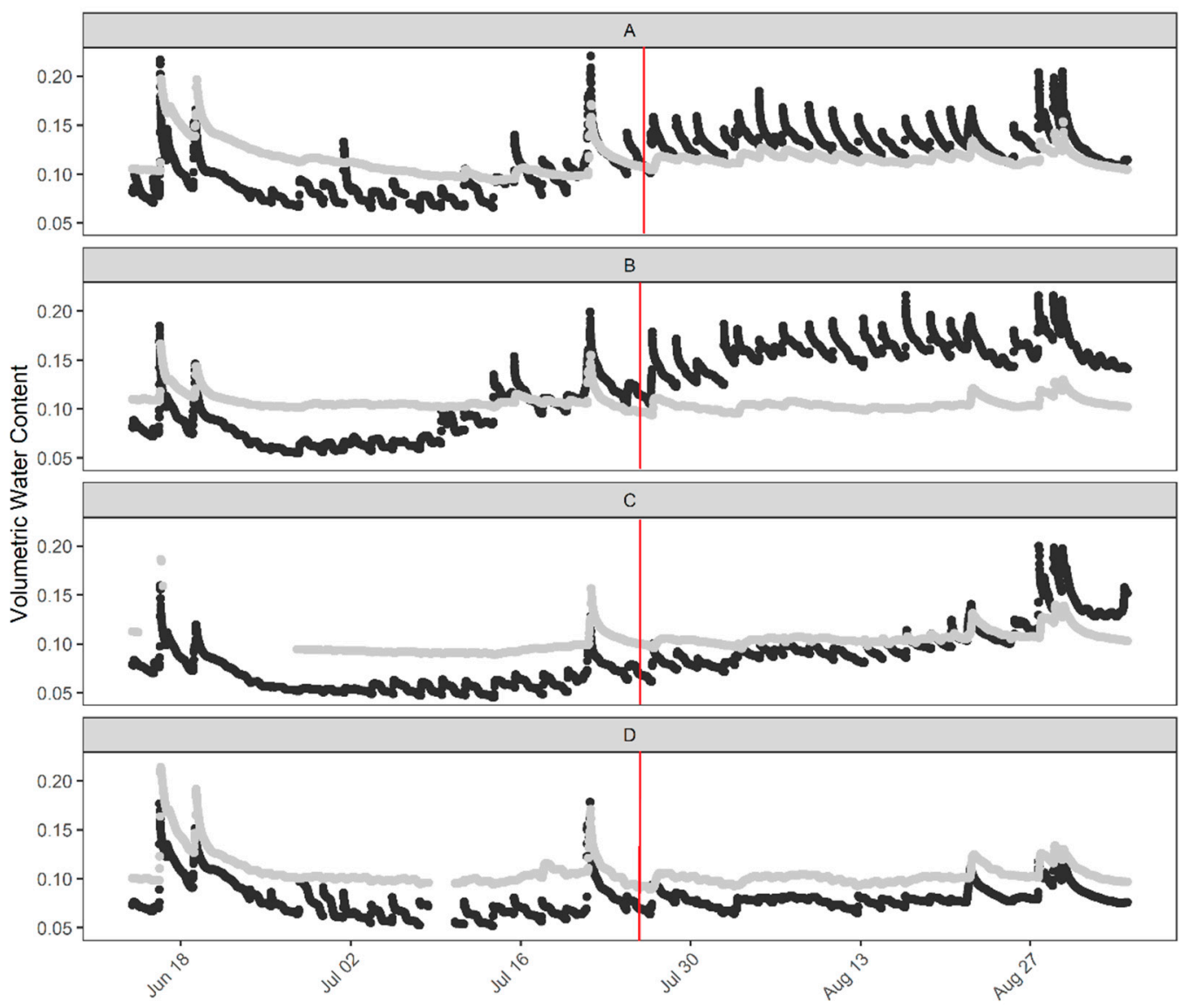

Figure 2. Volumetric Water Content (VWC) data from 2018 for treatment 1 (A), treatment 2 (B), treatment 3 (C), and treatment 4 (D). The black line indicates VWC at 0-30 cm soil depth, and the gray line indicates VWC at 30-60 soil depth. Start of the irrigation treatment, which was on 25 July, was marked by a red line. Gaps in the graphs are due to equipment errors.

The cumulative growing degree days from 1 May to 1 July from 2011 to 2019 is shown in Figure 4. For potatoes in Wisconsin, the period between May 1st and July 1st is the most critical time for tuber sprouting, tuber initiation, and early tuber bulking, all of which are closely associated with final tuber yield and quality [29]. The 2018 season had the most growing degree days in this 9-year period, while the 2019 season had the least. This suggests that those two seasons covered a range of extreme growing conditions in Central Wisconsin during the past 9 years. When considering the entire growing season, there were a total of 3486 growing degree days in 2018, while there were only a total of 2837 growing degree days in 2019.

Monthly soil water balance values for the non-treatment period of this experiment are displayed in Figure 5. The cumulative monthly ET values in 2019 were remarkably lower than those in 2018 for the early parts of the growing season. This is likely related to the low amount of growing degree days during the early growing season of 2019 (Figure 4). Monthly soil water balance under different irrigation rates during the treatment period are shown in Table 3. It is clear that compared to over-irrigation, regulated deficit irrigation when tubers reach late bulking can substantially reduce drainage (Figure 5). 


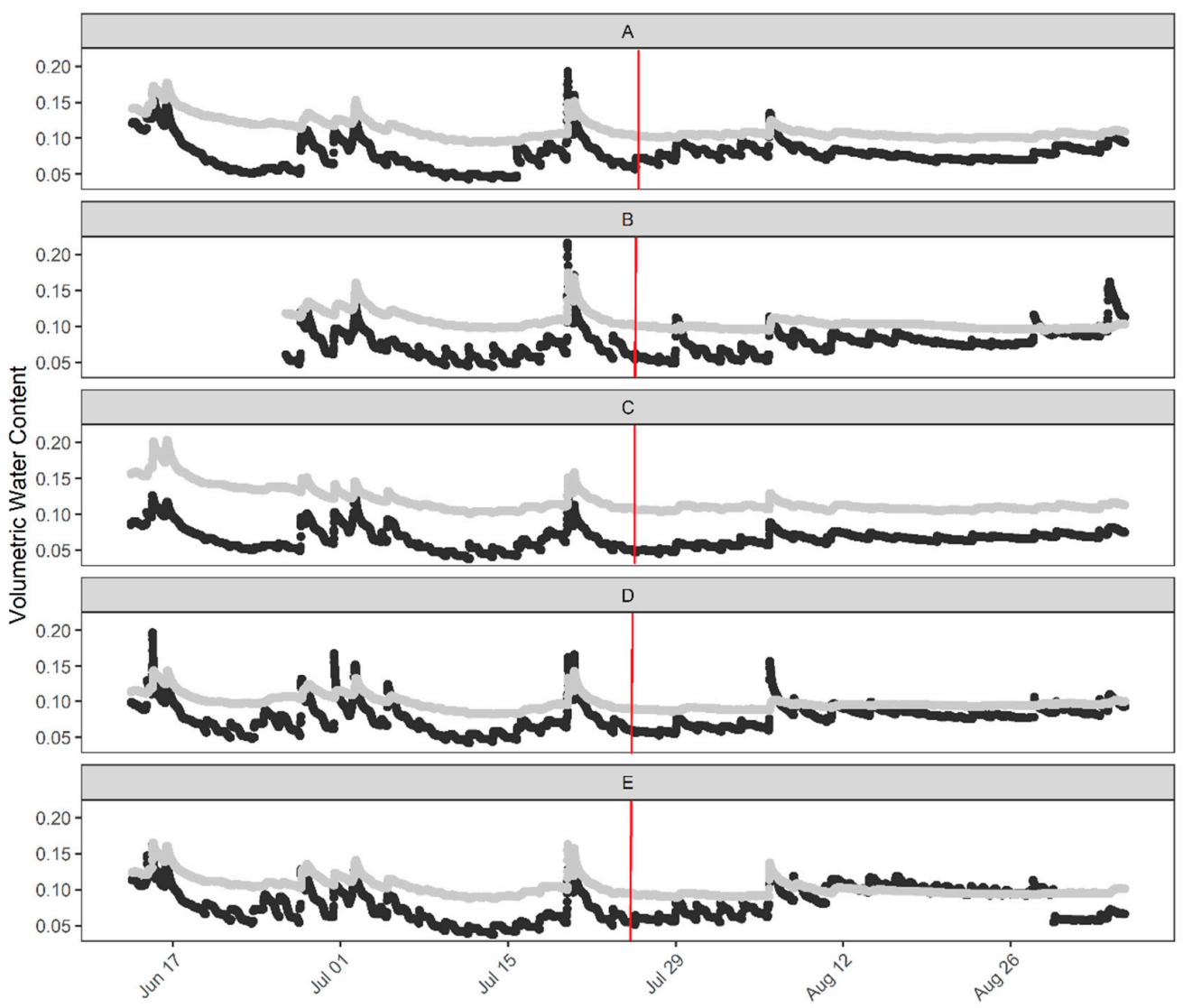

Figure 3. Volumetric Water Content (VWC) data from 2019 for treatment 1 (A), treatment 2 (B), treatment 3 (C), treatment 4 (D), and treatment 5 (E). The black line indicates VWC at 0-30 cm soil depth, and the gray line indicates VWC at 30-60 soil depth. Start of the irrigation treatment, which was on 25 July, was marked by a red line. Gaps in the graphs are due to equipment errors.

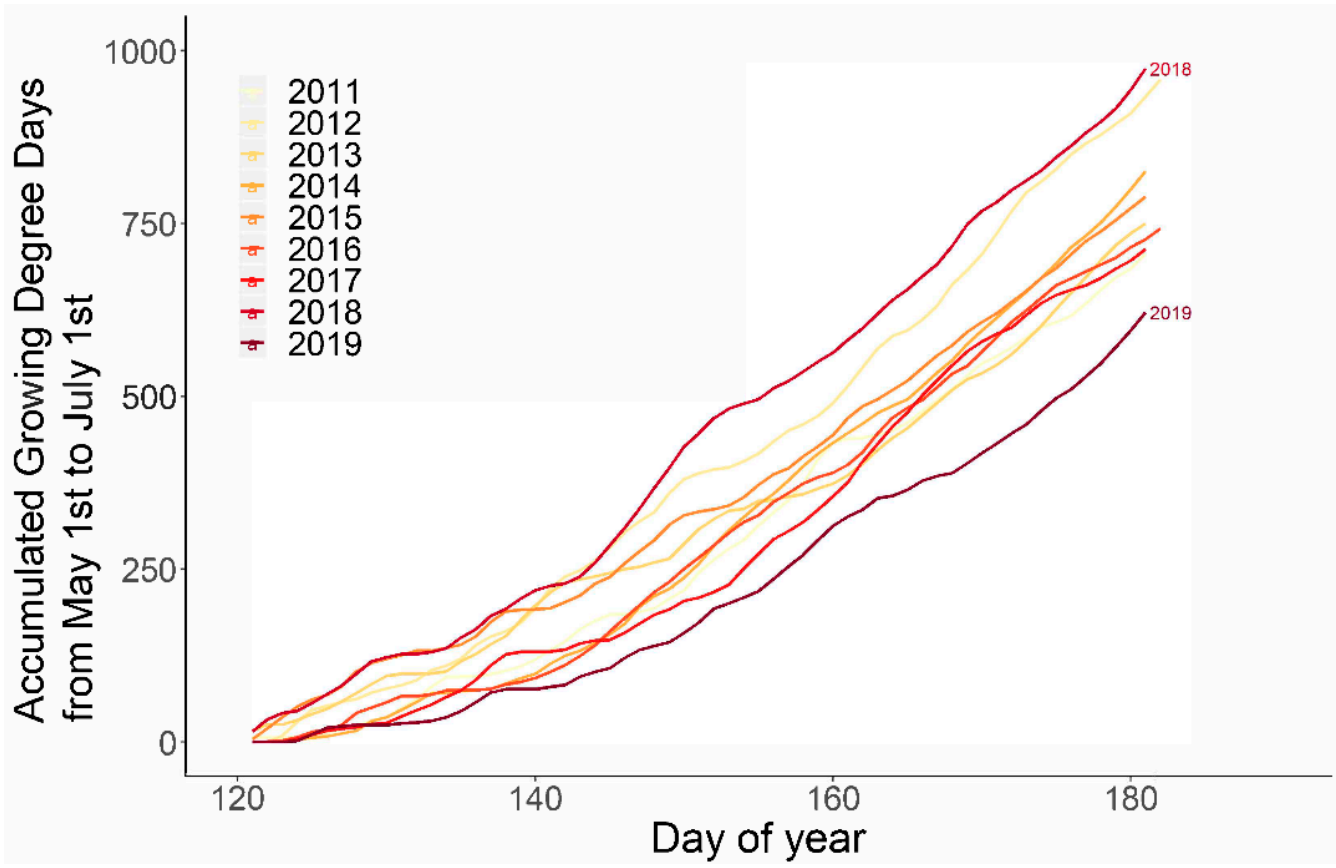

Figure 4. Cumulative Growing Degree Days, May 1st to July 1st, from 2011 to 2019. The years 2018 and 2019 are marked to show that they were the two extremes of the 9-year period. 


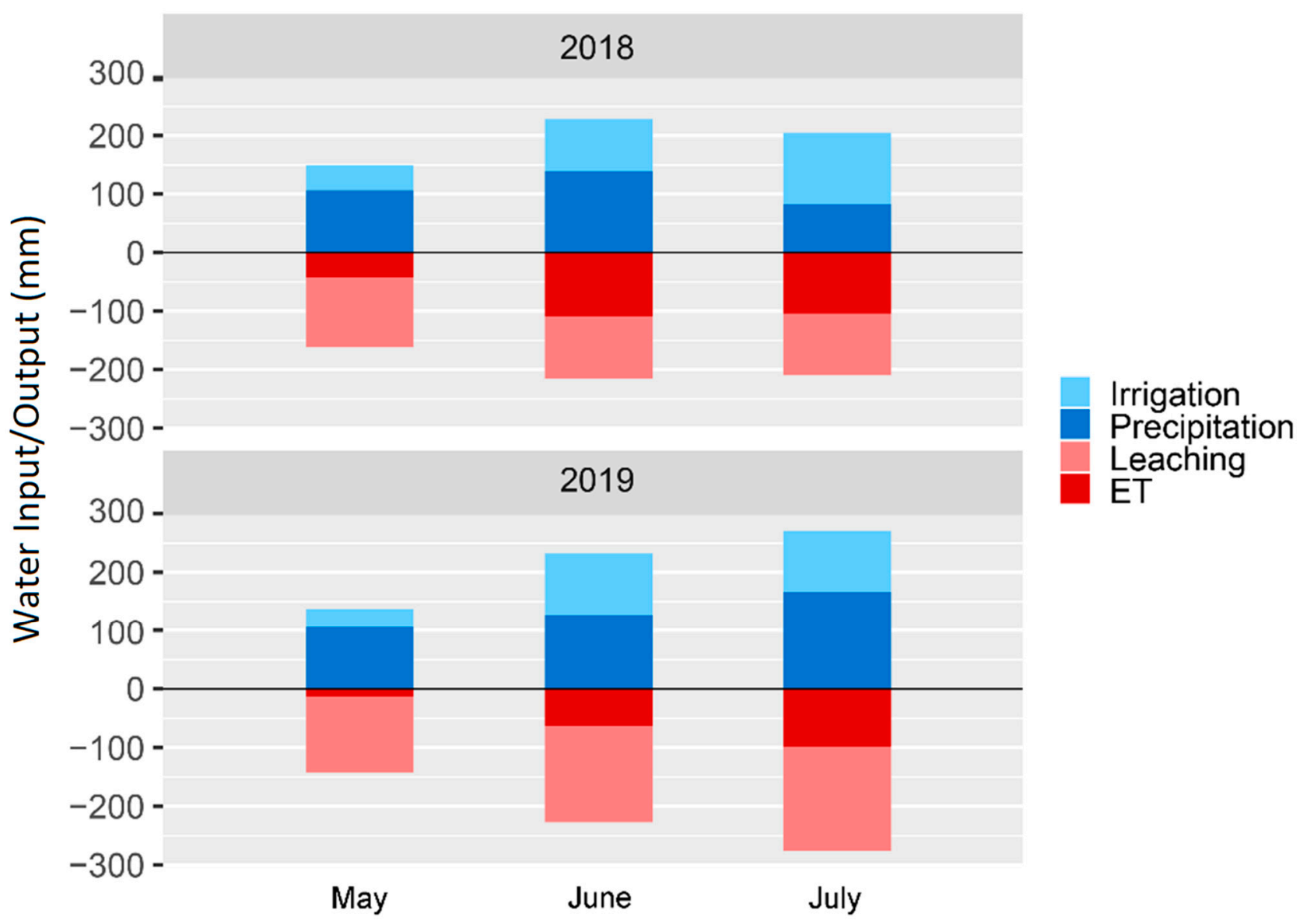

Figure 5. Monthly water balance values for the non-treatment period (planting to 24 July) for 2018 and 2019. All units are millimeters of water. Cumulative monthly values were calculated from daily collected data.

Table 3. Monthly water balance table for treatment period (25 July to vine kill) for all treatments in 2018 and 2019. Cumulative monthly values were calculated from data collected daily. NA: not available.

\begin{tabular}{|c|c|c|c|c|c|c|c|c|c|c|c|c|c|c|c|c|}
\hline & & \multicolumn{5}{|c|}{ July } & \multicolumn{5}{|c|}{ August } & \multicolumn{5}{|c|}{ September } \\
\hline & & 1 & 2 & 3 & 4 & 5 & 1 & 2 & 3 & 4 & 5 & 1 & 2 & 3 & 4 & 5 \\
\hline \multirow{2}{*}{ Irrigation (mm) } & 2018 & 48.3 & 40.6 & 33.0 & 25.4 & NA & 149.2 & 119.4 & 89.5 & 59.7 & NA & 0 & 0 & 0 & 0 & NA \\
\hline & 2019 & 41.3 & 33.0 & 23.8 & 16.5 & 23.8 & 106.4 & 85.1 & 63.8 & 42.6 & 56.2 & 25.4 & 20.3 & 15.2 & 10.2 & 10.2 \\
\hline \multirow{2}{*}{ Precipitation (mm) } & 2018 & 18.0 & 18.0 & 18.0 & 18.0 & NA & 180.6 & 180.6 & 180.6 & 180.6 & NA & 77.5 & 77.5 & 77.5 & 77.5 & NA \\
\hline & 2019 & 15.5 & 15.5 & 15.5 & 15.5 & 15.5 & 73.2 & 73.2 & 73.2 & 73.2 & 73.2 & 34.1 & 34.1 & 34.1 & 34.1 & 34.1 \\
\hline \multirow{2}{*}{$\mathrm{ET}(\mathrm{mm})$} & 2018 & 26.4 & 26.4 & 26.4 & 26.4 & NA & 89.2 & 89.2 & 89.2 & 89.2 & NA & 8.9 & 8.9 & 8.9 & 8.9 & NA \\
\hline & 2019 & 28.2 & 28.2 & 28.2 & 28.2 & 28.2 & 94.0 & 94.0 & 94.0 & 94.0 & 94.0 & 11.2 & 11.2 & 11.2 & 11.2 & 11.2 \\
\hline \multirow{2}{*}{ Leaching (mm) } & 2018 & 34.8 & 27.2 & 19.6 & 14.7 & NA & 244.5 & 214.6 & 184.8 & 152.2 & NA & 67.1 & 67.1 & 67.1 & 67.1 & NA \\
\hline & 2019 & 28.3 & 20.7 & 11.8 & 3.6 & 11.8 & 80.6 & 56.1 & 42.0 & 28.5 & 39.9 & 53.4 & 43.3 & 30.6 & 24.3 & 24.3 \\
\hline
\end{tabular}

\subsection{Yield and Size Profile}

The ANOVA results of traits measured at harvest are displayed in Table 4. There was not any significant two-way interaction between irrigation treatment and variety on the measured traits at harvest. While different irrigation treatments did have a significant effect on total yield in $2019(p=0.007)$, they did not affect total yield in $2018(p=0.349)$ or marketable yield in both $2018(p=0.107)$ and $2019(p=0.061)$. In 2019, total yield under rate 1 (over-irrigation) was not significantly different from that under rate 2 (standard irrigation). Total yield was significantly higher under these rates than under rate 4, which 
was the lowest deficit irrigation level (Figure 6). Harvest traits under rate 3 (75\%ET) was not significantly different from those under standard rate (100\%ET) in both years.

Table 4. At-harvest ANOVA for crop traits including total yield, marketable yield, hollow heart incidence, specific gravity, irrigation efficiency, and water-use efficiency indicated by total yield and marketable yield in 2018 and $2019 .{ }^{*} p<0.05$; ${ }^{* *} p<0.01 ;{ }^{* * *} p<0.001$.

\begin{tabular}{|c|c|c|c|c|c|c|c|c|}
\hline Source & Total Yield & $\begin{array}{c}\text { Marketable } \\
\text { Yield }\end{array}$ & $\begin{array}{l}\text { Hollow Heart } \\
\text { Incidence }\end{array}$ & $\begin{array}{l}\text { Specific } \\
\text { Gravity }\end{array}$ & $\begin{array}{c}\text { Irrigation } \\
\text { Efficiency } \\
\text { (Total Yield) }\end{array}$ & $\begin{array}{c}\text { Water-Use } \\
\text { Efficiency } \\
\text { (Total Yield) }\end{array}$ & $\begin{array}{c}\text { Irrigation } \\
\text { Efficiency } \\
\text { (Marketable } \\
\text { Yield) }\end{array}$ & $\begin{array}{c}\text { Water-Use } \\
\text { Efficiency } \\
\text { (Marketable } \\
\text { Yield) }\end{array}$ \\
\hline \multicolumn{9}{|c|}{2018} \\
\hline Rate & 0.349 & 0.107 & 0.462 & 0.394 & $0.004^{* *}$ & $0.032 *$ & $0.043 *$ & $0.004^{* *}$ \\
\hline Variety & $0.002 * *$ & $<0.001^{* * *}$ & 0.247 & $<0.001^{* * *}$ & 0.307 & 0.338 & 0.338 & 0.307 \\
\hline Rate $\times$ Variety & 0.424 & 0.137 & 0.087 & 0.712 & 0.600 & 0.629 & 0.620 & 0.599 \\
\hline \multicolumn{9}{|c|}{2019} \\
\hline Rate & $0.007^{* *}$ & 0.061 & 0.691 & 0.447 & $<0.001^{* * *}$ & $0.017 *$ & 0.976 & 0.936 \\
\hline Variety & $<0.001 * * *$ & $<0.001^{* * *}$ & 0.279 & 0.568 & $<0.001 * * *$ & $<0.001 * * *$ & 0.301 & 0.223 \\
\hline Rate $\times$ Variety & 0.724 & 0.728 & 0.517 & 0.455 & 0.748 & 0.735 & 0.748 & 0.735 \\
\hline
\end{tabular}

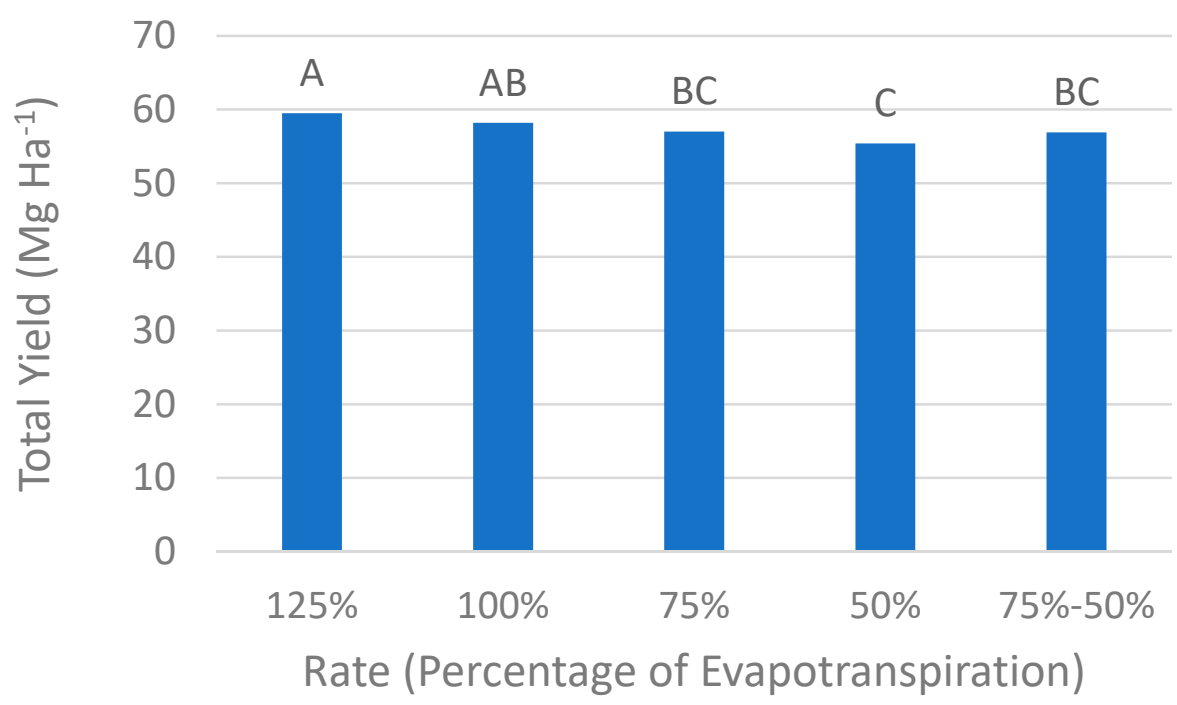

Figure 6. Total yield across the three varieties under each irrigation treatment in 2019. Bars with different letters are significantly different at $\alpha=0.05$.

Across the irrigation treatments, Silverton produced the highest total and marketable yield, whereas Russet Norkotah produced the lowest yield in both years.

For every variety, total and marketable yield was lower in 2019 than in 2018. In Russet Burbank, average total yield was $24 \%$ lower in 2019, and average marketable yield was $71 \%$ lower. In Silverton, average total yield was 21\% lower in 2019, with average marketable yield 51\% lower. For Russet Norkotah, average total yield was 23\% lower in 2019 than 2018, while average marketable yield was $64 \%$ lower. All of these are likely due to the 400 units fewer growing degree days during the most critical tuber growth stages in 2019 (Table 5).

Table 5. Total yield and marketable yield of the three varieties in 2018 and 2019. Within each column numbers followed by different letters are significantly different at $\alpha=0.05$.

\begin{tabular}{ccccc}
\hline \multirow{2}{*}{ Variety } & \multicolumn{2}{c}{$\mathbf{2 0 1 8}$} & \multicolumn{2}{c}{ 2019 } \\
\cline { 2 - 5 } & Total Yield & Marketable Yield & Total Yield & Marketable Yield \\
\cline { 2 - 5 } & & \multicolumn{3}{c}{$\mathbf{M g ~ h a}^{-\mathbf{1}}$} \\
\hline Russet Burbank & $76.2 \mathrm{a}$ & $40.0 \mathrm{c}$ & $58.1 \mathrm{ab}$ & $11.7 \mathrm{c}$ \\
\hline Russet Norkotah & $72.1 \mathrm{ab}$ & $47.0 \mathrm{~b}$ & $55.4 \mathrm{~b}$ & $17.0 \mathrm{~b}$ \\
\hline Silverton & $76.2 \mathrm{a}$ & $54.7 \mathrm{a}$ & $59.8 \mathrm{a}$ & $27.1 \mathrm{a}$ \\
\hline
\end{tabular}




\subsection{Tuber Quality at Harvest}

Incidence of hollow heart was not significantly affected by irrigation rate or variety in both years of the study (Table 4). Hollow heart incidence in all varieties were generally lower than $25 \%$. On tuber specific gravity, although irrigation rate did not have a significant impact in either year, effect of variety selection was significant (Table 4). In 2018, Russet Burbank showed higher specific gravity (1.073) than Russet Norkotah (1.063) or Silverton (1.062). This trend occurred in 2019, too, although the difference was not significant at $\alpha=0.05$.

\subsection{Irrigation Efficiency and Water-Use Efficiency}

In 2018, rate 4 (the lowest deficit irrigation level) resulted in significantly higher irrigation efficiency (IE) to produce both total yield and marketable yield than rate 1 (the over-irrigation treatment) (Figures 7 and 8). In 2019, IE for total yield increased significantly as irrigation rate decreased, with the lowest deficit irrigation level of rate 4 being the most efficient treatment, and IE for marketable yield was significantly higher under rate 4 than all the other treatments (Figures 7 and 8 ).

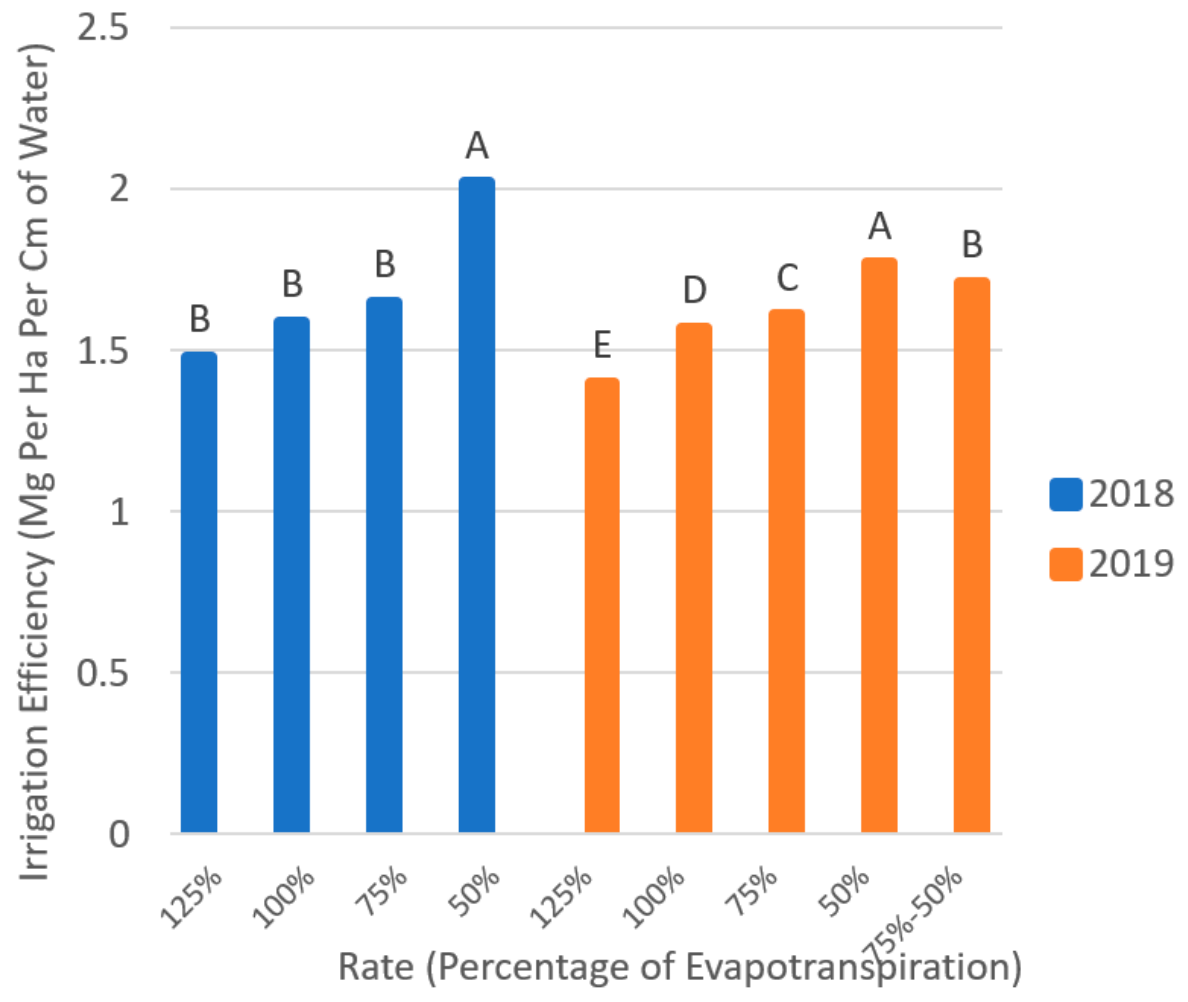

Figure 7. Irrigation efficiency (IE) for total yield in 2018 and 2019. For each year bars indicated by different letters are significantly different at $\alpha=0.05$.

Water-use efficiency (WUE), when considering crops' use of both irrigation and precipitation water, for producing total yield was significantly lower in the over-irrigated treatment than the lowest deficit irrigation treatment in 2018 and was significantly lower in the over-irrigated treatment than all other treatments in 2019 (Figure 9). WUE for producing marketable yield was significantly lower in rate 4 than in all other treatments in 2018, and was significantly lower in rate 4 than in rate 1 in 2019 (Figure 10). The difference in total water applied for the over-irrigation treatment (rate 1 at $125 \%$ ET) and the lowest deficit irrigation treatment (rate 4 at 50\%ET) between 25 July and vine kill was $12 \mathrm{~cm}$ in 2018 and $11 \mathrm{~cm}$ in 2019. Rate 3 at 75\%ET did not have different WUE values for total yield and marketable yield from the standard rate (rate 2) in both years (Figures 9 and 10). 


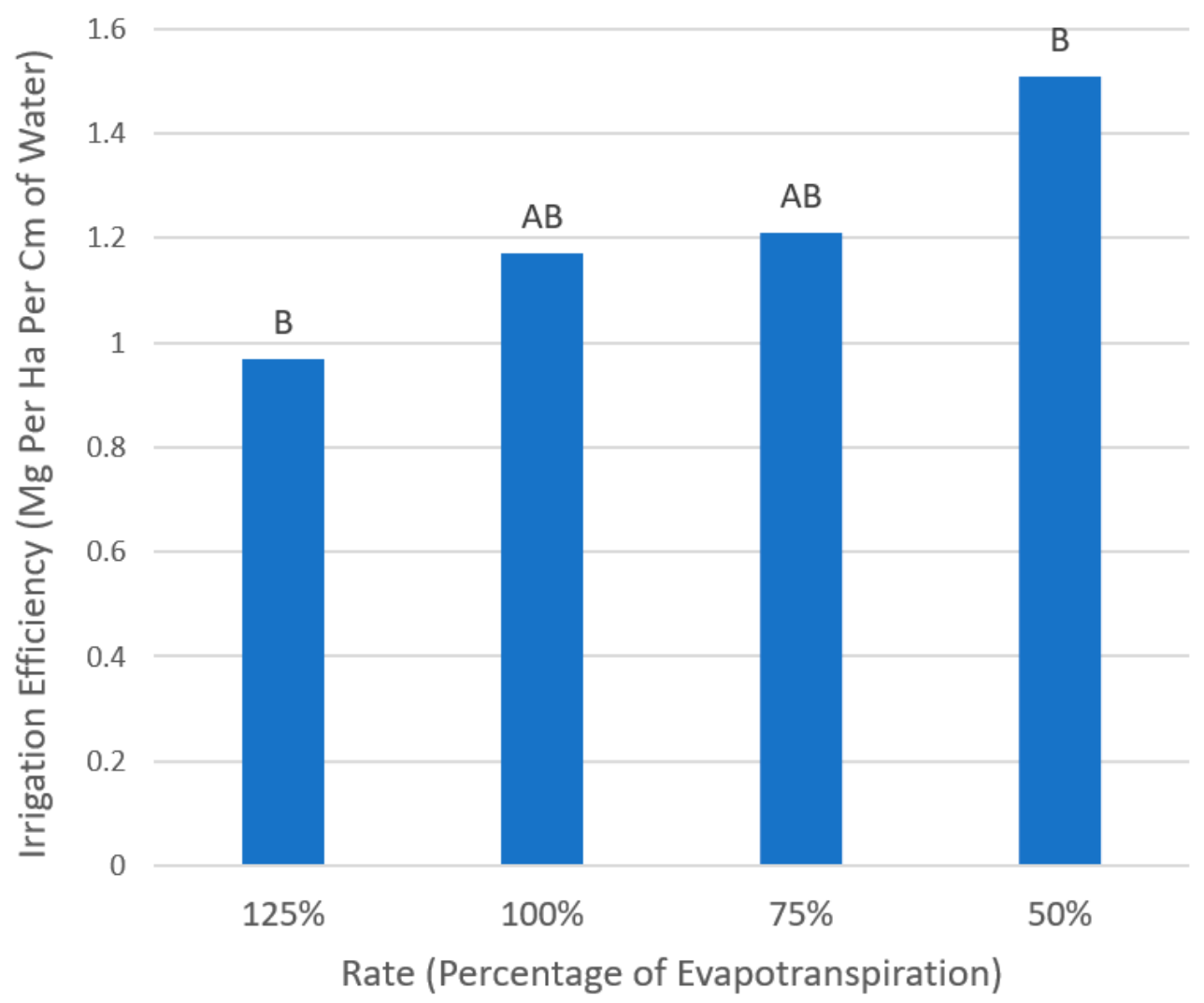

Figure 8. Irrigation efficiency (IE) for marketable yield in 2018. Bars indicated by different letters are significantly different at $\alpha=0.05$.

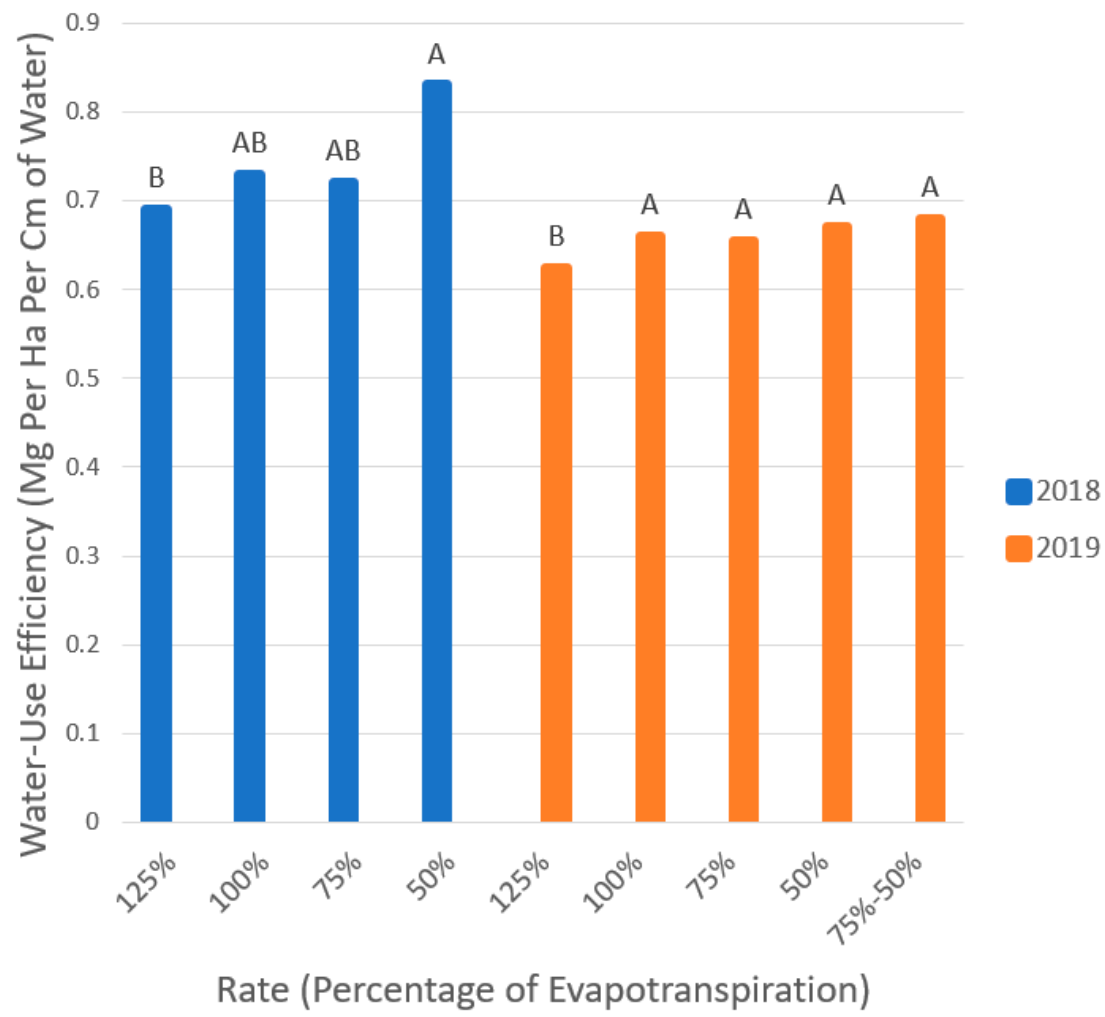

Figure 9. Water-use efficiency (WUE) for total yield in 2018 and 2019. For each year bars indicated by different letters are significantly different at $\alpha=0.05$. 
0.7

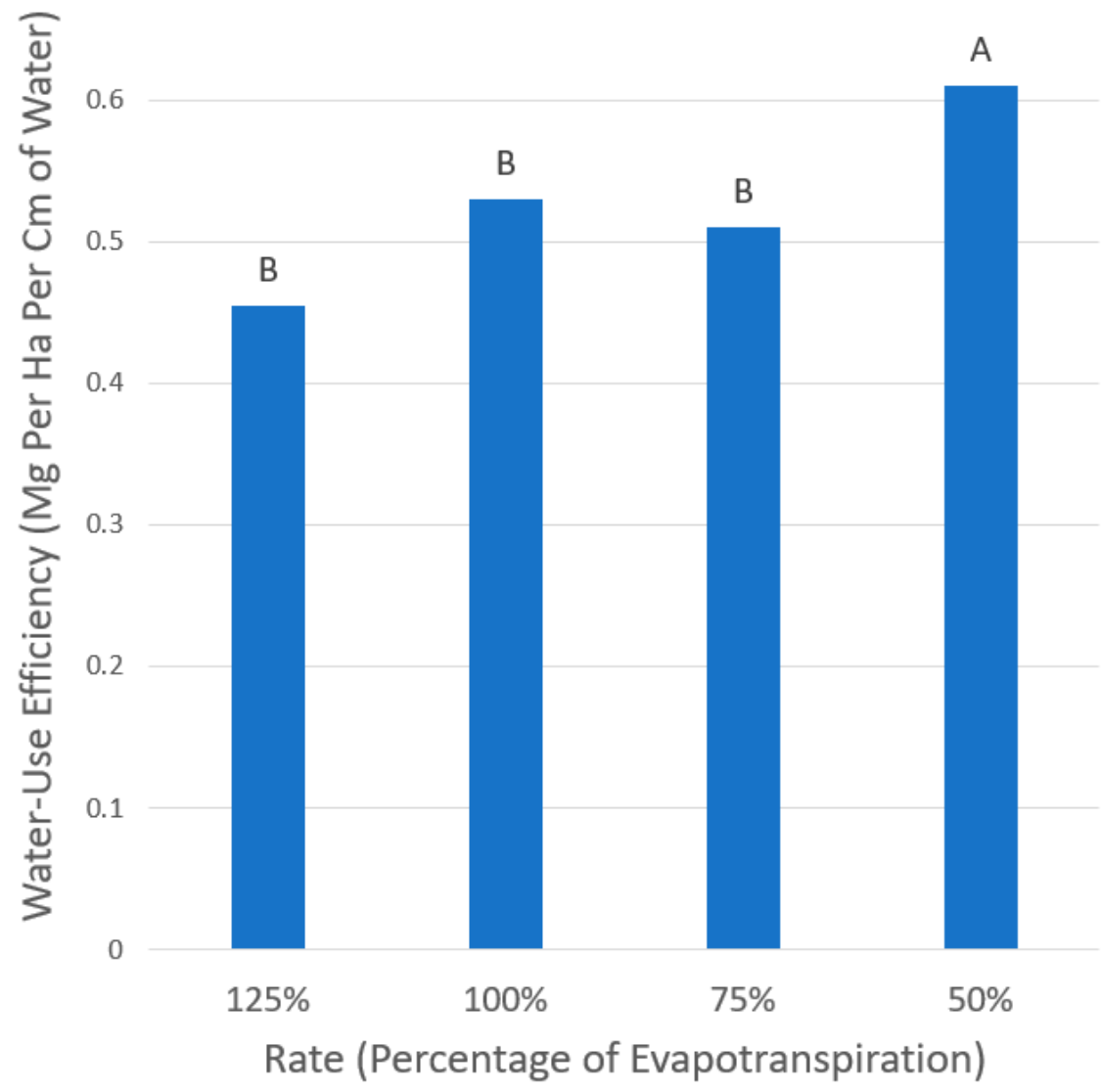

Figure 10. Water-use efficiency (WUE) for marketable yield in 2018. Bars indicated by different letters are significantly different at $\alpha=0.05$.

With regards to the significant varietal difference of IE and WUE for both total yield and marketable yield in 2019 (Table 4), Silverton had the highest values for both types of yield, while Russet Burbank had higher efficiency than Russet Norkotah for total yield but lower efficiency for marketable yield (Table 6).

Table 6. Irrigation efficiency and water-use efficiency for producing total yield and marketable yield of the three varieties in 2019. Within each column numbers followed by different letters are significantly different at $\alpha=0.05$.

\begin{tabular}{ccccc}
\hline \multirow{2}{*}{ Variety } & \multicolumn{2}{c}{ Irrigation Efficiency } & \multicolumn{2}{c}{ Water-Use Efficiency } \\
\cline { 2 - 5 } & Total Yield & $\begin{array}{c}\text { Marketable } \\
\text { Yield }\end{array}$ & Total Yield & $\begin{array}{c}\text { Marketable } \\
\text { Yield }\end{array}$ \\
\cline { 2 - 5 } & & $\mathbf{M g ~ h a}^{-\mathbf{1}} \mathbf{( c m ~ o f ~}^{*}$ Water) & \\
\hline Russet Burbank & $32.8 \mathrm{a}$ & $6.5 \mathrm{c}$ & $13.5 \mathrm{ab}$ & $2.7 \mathrm{c}$ \\
\hline Russet Norkotah & $31.1 \mathrm{a}$ & $9.5 \mathrm{~b}$ & $12.9 \mathrm{~b}$ & $4.0 \mathrm{~b}$ \\
\hline Silverton & $33.8 \mathrm{a}$ & $15.2 \mathrm{a}$ & $13.9 \mathrm{a}$ & $6.3 \mathrm{a}$ \\
\hline
\end{tabular}

\subsection{Storage Quality}

ANOVA results for storage quality of Russet Burbank potatoes from the 2018 and 2019 storage seasons are shown in Table 7. Irrigation treatments did not have any significant effects on any of the storage quality traits evaluated, and there were no significant twoway interactions between irrigation treatment and storage length in neither year. In 2018, storage length had significant effects on all measured storage traits except bud-end glucose 
concentration, with sucrose and glucose increasing and fry color worsening at 32 weeks after harvest. In 2019, a significant increase in glucose concentration on both bud end and stem end was observed at 32 weeks after harvest.

Table 7. ANOVA results for storage quality of Russet potatoes. ${ }^{*} p<0.05 ;{ }^{* *} p<0.01 ;{ }^{* * *} p<0.001$. NA: $p$-values for fry color of 2019 are not available.

\begin{tabular}{ccccccc}
\hline Source & $\begin{array}{c}\text { Stem-End } \\
\text { Sucrose }\end{array}$ & $\begin{array}{c}\text { Stem-End } \\
\text { Glucose }\end{array}$ & $\begin{array}{c}\text { Stem-End Fry } \\
\text { Color }\end{array}$ & $\begin{array}{c}\text { Bud-End } \\
\text { Sucrose }\end{array}$ & $\begin{array}{c}\text { Bud-End } \\
\text { Glucose }\end{array}$ & $\begin{array}{c}\text { Bud-End Fry } \\
\text { Color }\end{array}$ \\
\hline Rate & & 2018 & & 0.968 \\
Storage length & 0.826 & 0.122 & 0.517 & 0.829 & 0.433 \\
Rate $\times$ Storage length & $0.001^{* * *}$ & $0.002^{* *}$ & $0.037^{*}$ & $<0.001^{* * *}$ & $0.901^{* * *}$ \\
\hline & 0.294 & 0.903 & 0.968 & 0.306 & 0.737 \\
\hline Rate & & & 2019 & 0.413 & 0.356 \\
Storage length & 0.131 & 0.737 & NA & $0.008^{* *}$ & $<0.001^{* * *}$ \\
Rate $\times$ Storage length & 0.959 & $<0.001^{* * *}$ & NA & 0.188 & NA \\
\hline
\end{tabular}

\section{Discussion}

\subsection{Over-Irrigation Is Not Beneficial to Potato Yield, Quality, and Storage Quality in the} Upper Midwest

Irrigation treatment had little impact on traits measured at harvest (total yield, marketable yield, hollow heart incidence, and specific gravity) of this study (Table 3). The different irrigation regimes applied during the latter part of the growing season did not impact total yield or marketable yield in 2018, and only affected total yield that included culled potatoes in 2019 (Figure 6). Furthermore, total yield and marketable yield under the over-irrigation treatment was not significantly different than values under the standard irrigation practice in neither year.

Over-irrigation has been used by some growers as an "insurance practice" to achieve crop yield potential. However, potatoes that are over-irrigated during vegetative growth and tuber initiation are more susceptible to internal defects such as brown center and hollow heart, and can generally develop more early dying issues [5]. Additionally, potato yield can be reduced by over-irrigation during late growing season due to poor soil aeration and increased disease problems such as pink rot and Phythium leak infections [16,30]. Excessive soil moisture might also lead to swollen lenticels, shatter bruise due to raised tuber water content, and increased susceptibility to disease infections that are related to tuber storage quality issues [16,31]. More importantly, excessive irrigation together with the intense demand of potatoes for nitrogen fertilization is found to have a strong influence in increasing nitrate leaching into the groundwater, and causing water quality concerns in highly cultivated potato production systems [32,33].

\subsection{Deficit Irrigation in This Study Provides Potential for Water Use Sustainability}

This study showed that deficit irrigation, particularly at 75\%ET during the late season, did not jeopardize marketable yield, tuber quality at harvest, or tuber storage quality when compared to standard or over-irrigation treatments (Tables 4 and 5, Figure 7). Moreover, the increased irrigation efficiency and water-use efficiency (Figures 6-9) with a reduction in irrigation amount suggested that watering below the standard level $(100 \% \mathrm{ET})$ when potato plants are at their latter growing stages can result in more efficient use of water. Comparatively, watering above the standard level could cause significantly reduced irrigation efficiency and water-use efficiency. These results are in line with findings from Fabeiro et al. [34] and Badr et al. [35].

Stark et al. (2013) determined that late-season reduction in irrigation amounts during water shortages resulted in the highest reduction in yield loss for Idaho potato production. Ojala et al. [20] suggested that when limited irrigation must be implemented during seasons 
when water supplies were insufficient, higher total and US No. 1 yields of Russet Burbank can be obtained when irrigation deficits are avoided during mid-bulking or when limited water is distributed evenly over the course of the growing season. Paylista [36] stated that soil moisture can decline to $60-65 \%$ field capacity during potato maturation stage while not penalizing tuber yield. Our study, conducted in a humid Upper Midwestern location in the US, typically with adequate precipitation during potato growing seasons, suggested that reducing the irrigation rate to $75 \% \mathrm{ET}$ when tubers were at late bulking and maturation stages still enabled Russet Burbank, Russet Norkotah, and Silverton to maintain their yield potential. It needs to be pointed out that the two years when the irrigation treatments of this study were performed had medium to high precipitation records $(27.61 \mathrm{~cm}$ in 2018 and $9.96 \mathrm{~cm}$ in 2019) that might remediate some soil moisture stress for the plants, and therefore, further research needs to be conducted in dry years at the research location to investigate if similar results are achieved.

\subsection{Extreme Weather Conditions Require New Irrigation Management Strategies}

When a precipitation event that is larger than $1.3 \mathrm{~cm}$ occurs in the central sands region of Wisconsin, irrigation is not needed [25], preventing the irrigation treatments of this study from being effectively applied. In 2018, the long period of precipitation from 21 August to 9 September substantially disrupted rate 5, the split deficit irrigation rate that was supposed to start with 50\%ET on 20 August. A significant amount of commercial potato and vegetable fields in that year were also affected by this period of heavy rainfall, creating enlarged lenticels that were easy entry points to pathogens, causing storage issues, and even causing crops not to be harvested due to saturated field conditions [37].

In 2019, the abnormally low amount of growing degree days from 1 May to 1 July contributed to lower yield and smaller tuber sizes in 2019 compared to 2018. It is important to note that hollow heart was almost nonexistent in the 2019 tubers, most likely due to the reduced growing degree days and their consequence of poor yield in this year. Similar trends of lower yields in other vegetable crops such as peas, snap beans, and sweet corns were also noted in Central Sands in the 2019 growing season. Overall, while commercial growers faced similar pressures, they were able to respond to challenges presented by weather conditions and ultimately reported average to below average end-of-season yields with reductions in tuber size in 2019 [38]. Commercial growers are able to combat poor weather conditions by changing management plans throughout the season, such as with additional nitrogen applications or by delaying harvest to increase the length of the growing season. Research plots require consistent treatment across years, resulting in less flexibility and increased magnitude from the effects of challenging weather conditions.

A recent study has found that weather condition extremes, such as too hot and too cold temperatures, drought, and heavy precipitation, accounted for $18-43 \%$ of interannual variations in crop yield [39]. Extreme weather events are expected to affect the volatility of crop yields and are seen as the principal immediate threat to global crop production in the near future [40,41]. In addition to weather fluctuation, overall reduction in precipitation amounts have been observed in some regions [42]. Among the various adaptation measures, those related to variety development and modern irrigation technologies are considered more important [43]. In this study, substantial varietal difference was observed in both irrigation efficiency and water-use efficiency in 2019. Silverton had the highest efficiency values, while the least of the three was Russet Norkotah.

Modern irrigation technologies, such as precision irrigation, are being widely promoted to resolve challenges regarding improving crop productivity under current variable weather patterns. The variable rate irrigation (VRI) technology, an innovative system used in this study that applies varying rates of irrigation amount along the length of the center pivots based on specific crop water needs, field conditions, and varieties, is a potentially useful tool for efficient irrigation management to save water and reduce leaching potential [44]. VRI also helps to increase crop yield due to improved control of soil water in the crop rooting zone [45]. The present study illustrated the ability of VRI to 
be successfully utilized in potato irrigation management. Combined with methods such as soil mapping, this tool could be used to reduce overall irrigation application without sacrificing tuber yield.

\section{Conclusions}

Improving irrigation management practices is critical to achieving sustainable water use for potato production. This two-year study conducted in the Upper Midwest of the US indicated that over-irrigation at $125 \% \mathrm{ET}$ was not beneficial to profitable potato production in the studied region, and deficit irrigation at 75\%ET during late tuber bulking and tuber maturation could potentially result in more sustainable water use without jeopardizing tuber yield and quality at harvest or post-harvest storability. Growers could use the findings of this study to guide adjustments to their irrigation management decisions, allowing them to use water more efficiently without reducing the success of their crop.

Supplementary Materials: The following are available online at https:/ / www.mdpi.com/article/10 $.3390 /$ su131810187/s1, Table S1: soil classification properties of the study site, Table S2: pre-planting soil test results from 2018 and 2019, Table S3: nitrogen application history of the study.

Author Contributions: Conceptualization, methodology, Y.W.; formal analysis, investigation, data curation, writing —original draft preparation, T.W.C.; writing-review and editing, supervision, project administration, funding acquisition, Y.W. All authors have read and agreed to the published version of the manuscript.

Funding: This research was funded by the Wisconsin Potato and Vegetable Growers Association, and the United States Department of Agriculture Hatch Formula Funds.

Institutional Review Board Statement: Not applicable.

Informed Consent Statement: Not applicable.

Data Availability Statement: Data available on request due to restrictions.

Acknowledgments: The authors thank Paul Sytsma, Jerry Pierce, and the field crew at the University of Wisconsin Hancock Agricultural Research Station for providing field management assistance, particularly operating the VRI system to impose different irrigation treatments for this study. The authors thank Troy Fishler, Amber Gotch, and the storage crew at the University of Wisconsin Hancock Potato Research Facility for conducting storage quality evaluation. The authors also thank the Wisconsin Potato and Vegetable Growers Association for providing funds to support this research.

Conflicts of Interest: The authors declare no conflict of interest. The funders had no role in the design of the study; in the collection, analyses, or interpretation of data; in the writing of the manuscript, or in the decision to publish the results.

\section{References}

1. Hijmans, R.J. Global distribution of the potato crop. Am. J. Potato Res. 2001, 78, 403-412. [CrossRef]

2. National Potato Council. Potato Statistical Yearbook; NPC: Washington, DC, USA, 2018.

3. Keene, A.A.; Mitchell, P.D. Economic impact of specialty crop production and processing in Wisconsin; University of WisconsinExtension, 2010, Madison, WI, USA. Available online: https://aae.wisc.edu/pdmitchell/wp-content/uploads/sites/15/2019/09 /Crop_impacts.pdf (accessed on 20 January 2021).

4. Epstein, E.; Grant, W.J. Water Stress Relations of the Potato Plant under Field Conditions. Agron. J. 1973, 65, 400-404. [CrossRef]

5. King, B.A.; Stark, J.C.; Love, S.L. "Irrigation Management", Chapter 14. In Potato Production Systems; University of Idaho: Moscow, ID, USA, 2003.

6. Weeks, E.P.; Strangland, H.G. Effects of Irrigation on Streamflow in the Central Sand Plain of Wisconsin; US Department of the Interior, Geological Survey 1971; Water Resources Division: Madison, WI, USA.

7. Kniffin, M.; Potter, K.; Bussan, A.J.; Colquhoun, J.; Bradbury, K. Sustaining Central Sands Water Resources: State of the Science 2014; University of Wisconsin-Extension, Cooperative Extension: Madison, WI, USA, 2014; p. 45. Available online: https: / / learningstore.uwex.edu/Assets/pdfs/G4058.pdf (accessed on 20 January 2021).

8. Kraft, G.J.; Clancy, K.; Mechenich, D.J.; Haucke, J. Irrigation effects in the northern lake states: Wisconsin central sands revisited. Groundwater 2012, 50, 308-318. [CrossRef]

9. Spalding, R.F.; Exner, M.E. Occurrence of Nitrate in Groundwater-A Review. J. Environ. Qual. 1993, 22, 392-402. [CrossRef] 
10. Geerts, S.; Raes, D. Deficit irrigation as an on-farm strategy to maximize crop water productivity in dry areas. Agric. Water Manag. 2009, 96, 1275-1284. [CrossRef]

11. English, M. Deficit irrigation. I. Analytical framework. J. Irrig. Drain. Eng. 1990, 116, 400-402. [CrossRef]

12. Pereira, L.S.; Oweis, T.; Zairi, A. Irrigation management under water scarcity. Agric. Water Manag. 2002, 57, 175-206. [CrossRef]

13. Ünlü, M.; Kanber, R.; Senyigit, U.; Onaran, H.; Diker, K. Trickle and sprinkler irrigation of potato (Solanum tuberosum L.) in the Middle Anatolian Region in Turkey. Agric. Water Manag. 2006, 79, 43-71. [CrossRef]

14. King, B.A.; Stark, J.C. Potato Irrigation Management; University of Idaho, College of Agriculture: 1997. Available online: https:/ / www.cals.uidaho.edu/edcomm/pdf/BUL/BUL0789.pdf (accessed on 20 January 2021).

15. Van Loon, C.D. The effect of water stress on potato growth, development, and yield. Am. Potato J. 1981, 58, 51-69. [CrossRef]

16. Shock, C.C.; Pereira, A.B.; Eldredge, E.P. Irrigation best management practices for potato. Am. J. Potato Res. 2007, 84, 29-37. [CrossRef]

17. Thompson, A.L.; Love, S.L.; Sowokinos, J.R.; Thornton, M.K.; Shock, C.C. Review of the sugar end disorder in potato (Solanum tuberosum L.). Am. J. Potato Res. 2008, 85, 375. [CrossRef]

18. Dwyer, L.M.; Boisvert, J.B. Response to irrigation of two potato cultivars (Solanum tuberosum L. 'Kennebec' and 'Superior'). Can. Agric. Eng. 1990, 32, 197-203.

19. MacKerron, D.K.L.; Jefferies, R.A. The influence of early soil moisture stress on tuber numbers in potato. Potato Res. 1986, 29, 299-312. [CrossRef]

20. Ojala, J.C.; Stark, J.C.; Kleinkopf, G.E. Influence of irrigation and nitrogen management on potato yield and quality. Am. Potato J. 1990, 67, 29-43. [CrossRef]

21. Walworth, J.L.; Carling, D.E. Tuber initiation and development in irrigated and non-irrigated potatoes. Am. J. Potato Res. 2002, 79, 387-395. [CrossRef]

22. Stark, J.C.; Love, S.L.; King, B.A.; Marshall, J.M.; Bohl, W.H.; Salaiz, T. Potato cultivar response to seasonal drought patterns. Am. J. Potato Res. 2013, 90, 207-216. [CrossRef]

23. Yost, J.L. Soil Carbon and Soil Moisture Variation in Cropped Fields of the Central Sands in Wisconsin. Ph.D. Thesis, University of Wisconsin-Madison, Madison, WI, USA, 2016.

24. WISP: Wisconsin Irrigation Scheduling Program. Available online: https:/ /wisp.cals.wisc.edu/ (accessed on 29 June 2021).

25. Colquhoun, J.B.; Chapman, S.A.; Gevens, A.J.; Groves, R.L.; Heider, D.J.; Jensen, B.M.; Nice, G.R.W.; Ruark, M.D.; Wang, Y. Commercial Vegetable Production in Wisconsin. 2020. Available online: https://learningstore.extension.wisc.edu/products/ commercial-vegetable-production-inwisconsin (accessed on 20 January 2021).

26. Murphy, H.J.; Goven, M.J. Factors Affecting the Specicfic Gravity of the White Potato in Maine; Maine Agric Exp Stn Bull No 583. 1959.

27. Sowokinos, J.R.; Shock, C.C.; Stieber, T.D.; Eldredge, E.P. Compositional and enzymatic changes associated with the sugar-end defect in Russet Burbank potatoes. Am. J. Potato Res. 2000, 77, 47-56. [CrossRef]

28. R Core Team. R: A Language and Environment for Statistical Computing; 2019. Available online: http://www.r-project.org/ (accessed on 21 January 2021).

29. Crosby, T.W.; Wang, Y. Effects of Irrigation Management on Chipping Potato (Solanum tuberosum L.) Production in the Upper Midwest of the U.S. Agronomy 2021, 11, 768. [CrossRef]

30. Nolte, P.; Miller, J.S.; Geary, B.D.; Corsini, D.L.; Stark, J.C.; Love, S.L. “Disease Management”, Chapter 10. In Potato Production Systems; University of Idaho: Moscow, ID, USA, 2003.

31. Adams, S.S.; Stevenson, W.R. Water management, disease development, and potato production. Am. Potato J. 1990, 67, 3-11. [CrossRef]

32. Li, Y.; Li, J.; Gao, L.; Tian, Y. Irrigation has more influence than fertilization on leaching water quality and the potential environmental risk in excessively fertilized vegetable soils. PLoS ONE 2018, 13, e0204570. [CrossRef] [PubMed]

33. Trifonov, P.; Lazarovitch, N.; Arye, G. Water and nitrogen productivity of potato growth in desert areas under low-discharge drip irrigation. Water 2018, 10, 970. [CrossRef]

34. Fabeiro, C.; de Santa Olalla, F.M.; de Juan, J.A. Yield and size of deficit irrigated potatoes. Agric. Water Manag. 2001, 48, 255-266. [CrossRef]

35. Badr, M.A.; El-Tohamy, W.A.; Zaghloul, A.M. Yield and water use efficiency of potato grown under different irrigation and nitrogen levels in an arid region. Agric. Water Manag. 2012, 110, 9-15. [CrossRef]

36. Paylista, A.D. Potato Growth and Irrigation Scheduling. Available online: https://cropwatch.unl.edu/potato/plant_growth (accessed on 21 January 2021).

37. Wang, Y.; Naber, M.R.; Crosby, T.W. Effects of wound healing management on potato postharvest storability. Agronomy 2020, 10, 512. [CrossRef]

38. 2019 Wisconsin Potato Crop Report. Common'Tater. 2019. Available online: https://wisconsinpotatoes.com/wp-content/ uploads/2020/02/2001-Potato-Crop-Report-feature.pdf (accessed on 18 February 2021).

39. Vogel, E.; Donat, M.G.; Alexander, L.V.; Meinshausen, M.; Ray, D.K.; Karoly, D.; Meinshausen, N.; Frieler, K. The effects of climate extremes on global agricultural yields. Environ. Res. Lett. 2019, 14, 054010. [CrossRef]

40. Urban, D.; Roberts, M.J.; Schlenker, W.; Lobell, D.B. Projected temperature changes indicate significant increase in interannual variability of US maize yields. Clim. Chang. 2012, 112, 525-533. [CrossRef] 
41. Lobell, D.B.; Hammer, G.L.; McLean, G.; Messina, C.; Roberts, M.J.; Schlenker, W. The critical role of extreme heat for maize production in the United States. Nat. Clim. Chang. 2013, 3, 497-501. [CrossRef]

42. Padulano, R.; Lama, G.F.C.; Rianna, G.; Santini, M.; Mancini, M.; Stojiljkovic, M. Future rainfall scenarios for the assessment of water availability in Italy. In Proceedings of the 2020 IEEE International Workshop on Metrology for Agriculture and Forestry (MetroAgriFor), Trento, Italy, 4-6 November 2020; pp. 241-246. [CrossRef]

43. Varela-Ortega, C.; Blanco-Gutiérrez, I.; Esteve, P.; Bharwani, S.; Fronzek, S.; Downing, T.E. How can irrigated agriculture adapt to climate change? Insights from the Guadiana Basin in Spain. Reg. Environ. Chang. 2016, 16, 59-70. [CrossRef]

44. Hedley, C.B.; Yule, I.J.; Bradbury, S. Analysis of potential benefits of precision irrigation for variable soils at five pastoral and arable production sites in New Zealand. In Proceedings of the 19th World Soil Congress, Brisbane, Australia, 1-6 August 2010; pp. 1-6. Available online: https://iuss.org/19th\%20WCSS/Symposium/pdf/1104.pdf (accessed on 22 January 2021).

45. Perea, R.G.; Daccache, A.; Díaz, J.R.; Poyato, E.C.; Knox, J.W. Modelling impacts of precision irrigation on crop yield and in-field water management. Precis. Agric. 2018, 19, 497-512. [CrossRef] 